\title{
Mammut borsoni (HAYs 1834) from the Early Pliocene of Husnicioara (Mehedinți district, Romania)
}

\author{
Vlad A. CODREA ${ }^{1 *} \&$ Florina DIACONU² \\ ${ }^{1}$ Department of Geology and Paleontology, „Babeş-Bolyai“ University, Kogălniceanu 1, 400084 Cluj Napoca, Romania \\ ${ }^{2}$ Porților de Fier Museum, 2 Independenței Str., Drobeta-Turnu Severin, Romania
}

Received July 2007; accepted December 2007

Available online 10 december 2007

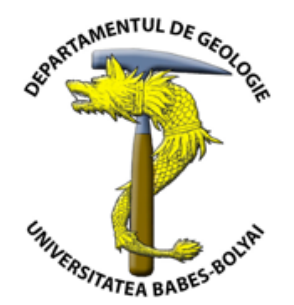

Abstract. A mastodon tooth has been found at Husnicioara coal open pit, in Mehedinți district (southwestern Romania). It originates from the Lower Pliocene (Dacian) gravel and sand deposits lying just above the coal bed IV, mined in this quarry. The tooth exposing zygodont features undoubtedly belongs to Mammut borsoni ("Borson's mastodont"). Although this species is very common in the Pliocene vertebrate faunas from this part of Europe, until now it was missing from the Lower Pliocene (Dacian) assemblage's lists in our country.

Key words: Early Pliocene, zygodont mastodon, SW Romania.

\section{INTRODUCTION}

Husnicioara open pit (located in Mehedinţi district, Romania) is among the largest Pliocene coal quarries still active in Oltenia. Here, lignite is mined from both Dacian and Romanian deposits. The basal lignite beds from this area (A-D, I-IV) belong to the Berbeşti Formation (Getian $=$ Early Dacian), those located above bed IV being assigned to the Jiu-Motru Formation (Parscovian-Siensian = Late Dacian-Early Romanian; Andreescu et al., 1985). However, according to other opinions, the coal bed IV could also belong to the Late Dacian (Enciu, 2007). If we are taking into consideration the Pliocene chronostratigraphic framework for the Dacic Basin recommended by Snel et al. (2006), the coal bed IV from Husnicioara could firstly belong to the Getian, as it is included into the Sidufjall subchron base (C3n3n; Popescu et al., 2006). Anyhow, conclusively, all these interpretations locate the coal bed IV either at the top of the Getian, or in the lowermost Parsovian.

Several contributors (e.g., Petrescu et al., 1989; Codrea and Diaconu, 2003) described in detail the geology of Husnicioara open pit. For this reason, we will not describe the deposits here, but only illustrate them (Fig. 1).

Apart the economic interest, the deposits cropping out at Husnicioara are well known for their plant and invertebrate fossil content (Petrescu et al., 1989). Even if scarce, vertebrate fossils also occur. Until now, some large herbivores bones have been described either from the Late Pliocene (Romanian) beds or from the Pleistocene cover overlying the Pliocene deposits, as shown by Codrea and Diaconu (2003).

In 2005 Irel Diaconu, mining engineer at Husnicioara, collected a mastodon tooth from the quartz sand and gravel deposits lying on the top of the coal layer IV (Fig. 2). These sands and gravels almost entirely consist of medium to coarse white quartz, with subordinate white mica (muscovite) content, as well as lithoclasts mainly originating from metamorphic or magmatic source-areas (retromorphic gneiss, gneiss, andesite, epidote monzodiorite, pyroxene gabbro, granite, sericite-epidote schist, chlorite quartzite, quartzite sandstone etc.). These deposits accumulated in shore lake environments, the clastic rocks probably resulting by sedimentary input coming from the folded Carpathian realm.

The tooth was relieved from its matrix in the Vertebrate Laboratory of the Babeş-Bolyai University in Cluj-Napoca, and then curated at the Porților de Fier Region Museum in Drobeta-Turnu Severin (abbreviated PFRM).

\section{SYSTEMATIC PALEONTOLOGY}

Order Proboscidea ILLIGER, 1811

Family Mammutidae HAYS, 1922

Genus Mammut BLUMENBACH, 1799

Mammut borsoni HAYS, 1834 (Pl. I, Figs. 1-2).

\section{Material}

Left M2, PFRM 1840 (dental nomenclature, according to Tobien, 1996).

\section{Measurements}

$\mathrm{L}=118.5 ; \mathrm{W}_{(1)}=87 ; \mathrm{W}_{(2)}=91 ; \mathrm{W}_{(3)}=93 ;$ Width ratio: $100 \mathrm{~W}$ max./L (Tassy, 1977) $=78.48$; Length/Width ratio: $100 \mathrm{~L} / \mathrm{W} \max =127$; Breadth of ridges (transversal distance of main cusps according to Kubiak, 1972): $\mathrm{B}_{(1)}=55 ; \mathrm{B}_{(2)}=$ 57; $\mathrm{B}_{(3)}=58$; Height max.: 55 (postero-labial); Height max. of cingulum: 24; Hypsodonty index: $100 \mathrm{H} / \mathrm{L}=46.41$ (mm; the numbers in brackets are indicating the transverse ridges). 


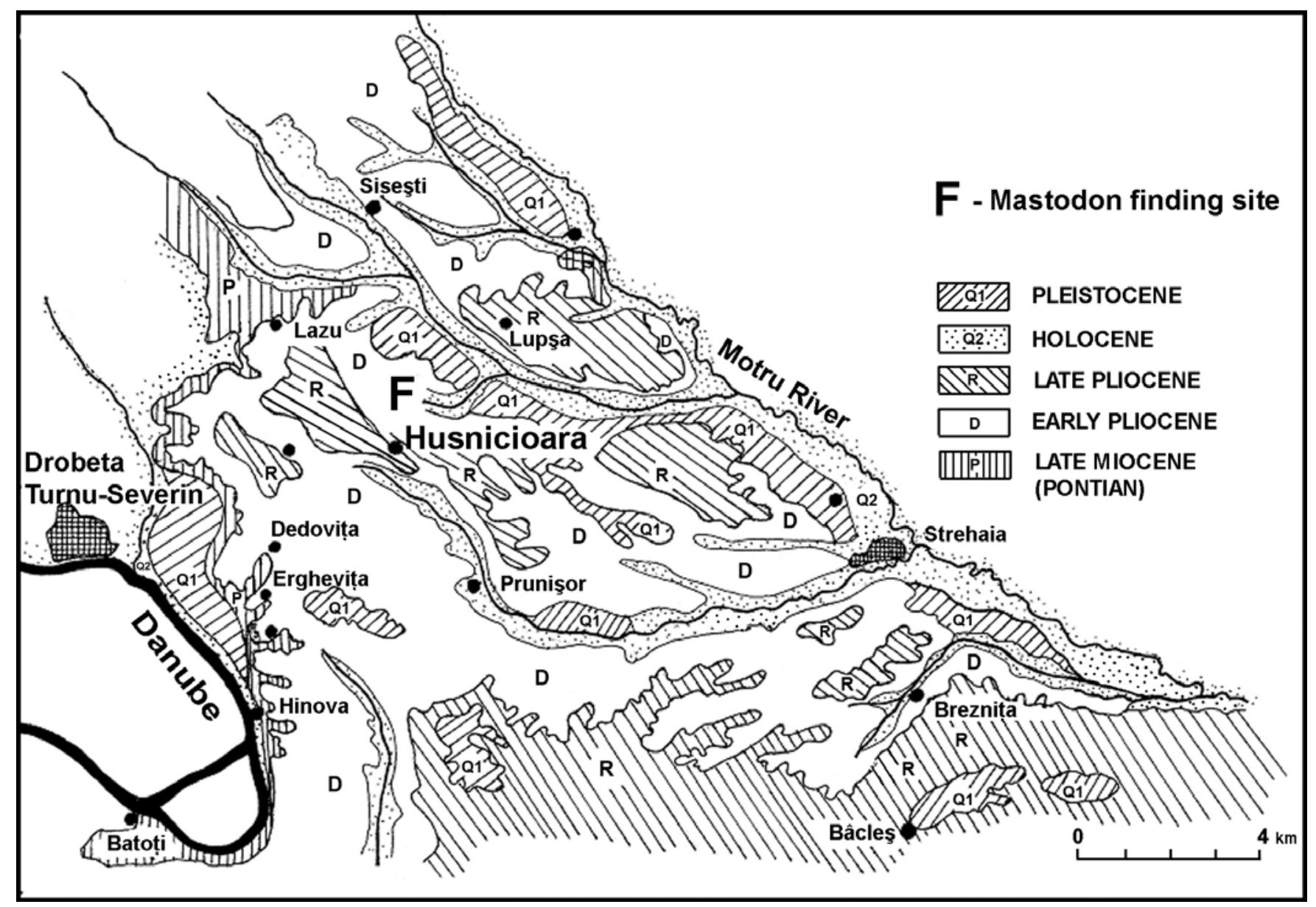

Fig. 1. Geological map of the Husnicioara area.

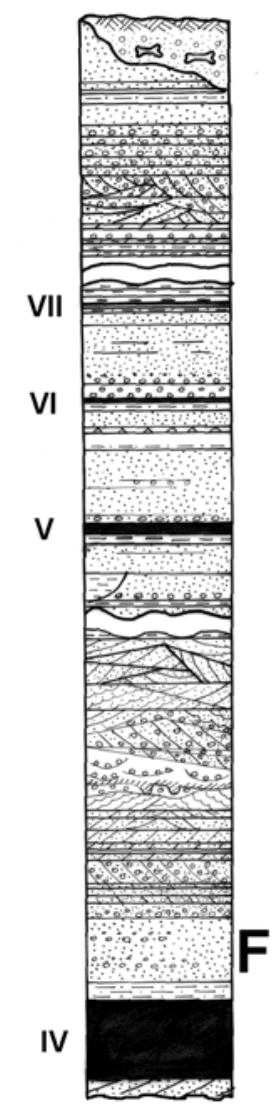

Fig. 2. Log of Husnicioara Pliocene succession. F represents the level from where the mastodon tooth originated.

\section{Description}

Only one isolated cheek upper tooth documents this mammutid species in the Dacian deposits at Husnicioara. It belonged to a young mature specimen. According to the wearing and pressure marks, it is obvious that this tooth was not physiologically lost during the animal's lifetime, but it was put apart from the upper tooth row only after its death, then carried by the water streams into the Dacian Lake. As a consequence, the tooth preserved only its whole crown, devoid of roots; the latter probably had been broken apart before the fossil burial, as a consequence of the stream rolling process.

The molar has rounded rectangular outline. It belongs to the trilophodont type with large opened, straight transverse valleys. The three transversal lophs are also straight, completely open, devoid of conulus on their tracks. The crown is nearly pristine, with strictly incipient attrition. Only weak wear marks can be noted on the anterior and posterior crescentoids of the protocone, as well as on the anterior crescentoid of the hypocone. On the posttrite halflophs, these wear marks can be observed only on the anterior wall of the second ridge. Due to the age of the individual, a pressure mark documents only the contact with M1, the distal one being absent. Thus, it is obvious that M3 had not been erupted. A continuous strong cingulum surrounds almost the entire tooth, excepting the palatal endings of the second and third posttrite half-lophs. Its maximum height is on its distal, postero-labial side. The outlines of the ridge transverse sections are bold on the labial sides and gentle on the palatal ones (Fig. 3). The 
pretrites half-lophs bear somewhat smaller number of conelets compared to the posttrites ones, excepting the distal ridge, where the situation is reversed. The median sulcus is well expressed on each transverse ridge, however fainter on the distal one.

In lateral view, one can mention the symmetrical display of the anterior and posterior wall slopes of the second and third ridges. On the contrary, the first ridge is asymmetric, with an abrupt anterior wall and a gentle slope of the posterior one.

The tooth size is close to those indicated from some other species' localities (Kubiak, 1972). However, the tooth is larger than the ones from Velké Bielice (Slovakia, Early Pliocene; Holec, 1985) or most of all, from Milia (Greece, Ruscinian, MN 14/15), where a very peculiar specimen with small cheek teeth and huge tusk had been unearthed (Tsoukala, 2000).

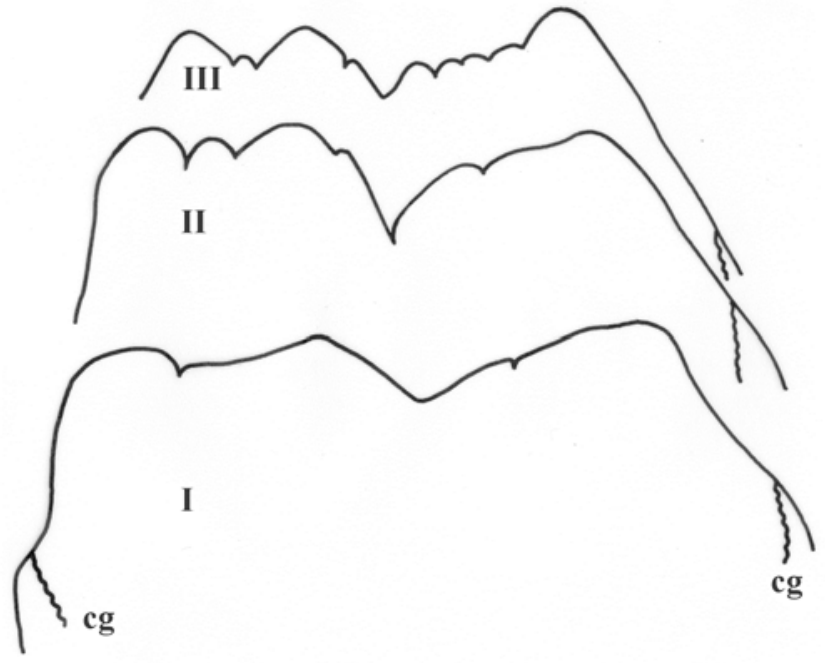

Fig. 3. Transverse lophs profiles of the mastodon tooth.

\section{DISCUSSION}

M. borsoni is a common proboscidean in the Upper Miocene-Lower Pleistocene formations in Central and Eastern Europe, being often recorded in the mammal assemblages described from the countries surrounding Romania (Schlesinger, 1922; Bakalov and Nikolov, 1962; Mitzopoulos, 1967; Kubiak, 1972; Holec, 1985, 1992; Lungu and Obadă, 2001; Holec et al., 2002).

In spite of over a century of research on the Pliocene in Romania, the Dacian vertebrate localities still remain extremely rare (Rădulescu and Samson, 1995; Rădulescu et al., 1998; Terzea, 1983, 2006). Moreover, the Getian (Early Dacian) mammal representatives are practically unknown (Terzea, 2005). Until now, no proboscidean was reported from these few Dacian mammal assemblages in the mentioned references. Therefore, the finding from Husnicioara represents a significant result in a tentative to fill this gap.

The first consistent overview on $M$. borsoni in Romania belonged to Athanasiu (1907). He mentioned this species from several localities from the former Romanian Kingdom, more exactly from Muntenia and Moldova. Unfortunately, his stratigraphical information on most of these localities is extremely scarce and rather unclear. In the Mehedinți district, Palota is the only locality from where he reported this proboscidean (in fact, more probably the correct locality name is Balota). One can suppose that at least in the case of some of these localities, like Curtea de Argeş (Pârăul Târgului), the host rocks could be represented by Dacian deposits, as later stressed out by Macarovici (1978).

Following Athanasiu's paper (1907), for several decades no other contribution contained reliable data on this mammutid. Most of the publications (Barbu, 1930; Simionescu and Barbu, 1943; Apostol, 1968; Macarovici, 1978) contained only lists of localities, usually reiterating the ones already mentioned by Athanasiu and additionally including those indicated by Simionescu (1930).

Inside the Carpathians, the localities from where this mastodon is reported are even less numerous, because the areas exposing Upper Miocene-Pliocene formations are more restricted. The most interesting region is the Pliocene Basin of T,ara Bârsei, where M. borsoni have been reported from Căpeni, Vârghiş, Iaraş-1, Araci-Fântâna Fagului (MN 15 b-MN 16; Rădulescu et al., 2003).

Surprisingly, in western Romania this species is still absent (Jurcsák, 1973, 1983) but a related species - perhaps its ancestor - Mammut praetypicum (SCHLESINGER 1919), has been mentioned (for details, see Codrea et al., 2005).

\section{CONCLUSION}

It is no doubt that $M$. borsoni existed in the Dacian mammal assemblages, as clearly evidenced by its presence at Husnicioara on the top of the coal bed IV. Subsequently, during the Late Pliocene (Romanian) its frequency increased, as proven by the large number of such sites, most of them located in Oltenia.

The species populated the emerged land ripparian to the Dacic Lake. These probably dense forested areas offered a convenient environment for this squeezer, the vegetation being rich in thermophilous trees mostly located in low altitudes areas of the Dacic Basin. The environment of the Husnicioara coal bed IV sequence probably evolved during an Early Pliocene warm phase (Popescu, 2001). The Pliocene deposits that yielded the mammutid tooth from Husnicoara belong to the MN 14 unit, this proboscidean being a representative of the Ruscinian faunas.

Acknowledgements. The authors are thankful to Nicolae Har, senior lecturer at "Babeş-Bolyai" University for his help in the determination of the clastic rocks. We are also grateful to Peter Holec (Bratislava University) and Márton Venczel (Țării Crişurilor Museum, Oradea) for their valuable remarks and collegial help. We address special thanks to Evanghelia Tsoukala (Aristotle University, Thessaloniki) for her help in obtaining valuable data on the Milia mastodons. Same acknowledgements are directed to several colleagues from the "Babeş-Bolyai" University, for their contribution in improving the English version. The 12/225/2007 Education and Research Ministry Grant (CNCSIS) to V.A.C. financially supported this study.

\section{R E F E R E N C E S}

Andreescu, I., T,icleanu, N., Pană, I., Pauliuc, S., Pelin, M. \& Barus, T. 1985, Stratigraphie des dépôts pliocènes à charbons - zone est d'Oltenie (secteur Olt-Jiu). Analele Universității Bucureşti, XXXIV: 87-96.

Apostol, L. 1968, Particularité morphologiques des molaires de proboscidiens fossiles quaternaires de Roumanie, 
conservées dans la collection du Musée d'Histoire Naturelle „Grigore Antipa”. Travaux du Muséum d'Histoire Naturelle „Grigore Antipa”, IX: 581-616.

Athanasiu, S. 1907, Contribuțiuni la studiul faunei terțiare de mamifere din România. Anuarul Institutului Geologic al României, I (1): 129-214.

Barbu, I.Z. 1930, Catalogul vertebratelor fosile din România. Academia Română, Memoriile Secțiunii Ştiințifice, Seria III, VII (2): 7-23.

Bakalov, P., Nikolov, I. 1962, Mammifères tertiaires. Les fossiles de Bulgarie, 10: 1-162 (in Bulgarian, with French abstract).

Codrea, V., Diaconu, F. 2003, Plio-Pleistocene large herbivores from Husnicioara (Mehedinți Department). Studii şi cercetări, Geologie-Geografie, 8: 73-86.

Codrea, V., Venczel, M. \& Popa, E. 2005, New finding of Mammut praetypicum (Proboscidea, Mammalia), a zygodont mastodon from Păgaia (NW Romania). Acta Palaeontologica Romaniae, 5: 67-71.

Enciu, P. 2007, Pliocenul şi Cuaternarul din vestul Bazinului Dacic. Stratigrafie şi evoluție paleogeografică. Ed. Academiei Române, Bucureşti, 228 p.

Holec, P. 1985, Finds of mastodon (Proboscidea, Mammalia) Relics in Neogene and Quaternary Sediments of Slovakia (CSFR). Západné Karpaty, 10: 13-53.

Holec, P. 1992, Výliatky zubov mastodonta druhu Mammut borsoni (Hays, 1834) v dreveníckom travertine pri Spišskom Podhradi. Mineralia Slovaca, 24: 467-469.

Holec, P., Kováč, M., Sliva, L., Vojtko, R. \& Joniak, P. 2002, Nález mastodonta Mammut borsoni (Hays, 1834) pri Cerovinách-litologické pomery a stratigrafia. Mineralia Slovaca, 34: 353-358.

Jurcsák, T. 1973, Răspîndirea mastodonților la vest de Munții Apuseni. Nymphaea, I: 313-341.

Jurcsák, T. 1983, Răspîndirea proboscidienilor în nordvestul României. Nymphaea, X: 65-85.

Kubiak, H. 1972, The Skull of Mammut praetypicum (Proboscidea, Mammalia) from the Collection of the Jagiellonian University in Cracow, Poland. Acta Zoologica Cracoviensia, XVII (13): 305-324.

Lungu, A., Obadă, T. 2001, Contributions to the study of the Neogene representatives of Ordo Proboscidea (Mammalia) from Eastern Europe. The World of Elephants International Congress, Abstracts: 119-121, Rome.

Macarovici, N. 1978, Sur la faune de mammifères fossiles néozoiques de la Roumanie. Revue Roumaine de Géologie, Géophysique et Géographie, Géologie, 22: 71-98.

Mitzopoulos, M.K. 1967, Zygolophodon borsoni und Anancus arvernensis aus dem Oberpliozän von Griechenland. Annales Géologiques des Pays Helléniques, 18: 436-446.

Petrescu, I., Cernita, P., Meilescu, C., Codrea, V., Pascovici, N., Vădan, M., Hosu, A., Manda, S. \& Bengulescu, L. 1989, Preliminary approaches to the palynology of the Lower Pliocene (Dacian) deposits in the Husnicioara area (Mehedinți County, SW Romania). Studia Universitatis Babeş-Bolyai, Geologie-Geografie, 34 (2): 67-74.
Popescu, S.-M. 2001, Repetitive changes in Early Pliocene vegetation revealed by high-resolution pollen analysis: revised cyclostratigraphy of southwestern Romania. Review of Palaeobotany and Palynology, 120: 181-202.

Popescu, S.-M., Krijgsman, W., Suc, J.-P., Clauzon, G., Mărunțeanu, M. \& Nica, T. 2006, Pollen record and integrated high-resolution chronology of the early Pliocene Dacic Basin (southwestern Romania). Paleogeography, Paleoclimatology, Paleoecology, 238: 78-90.

Rădulescu, C., Samson, P. 1995, The mammals of the Dacian. In Chronostratigraphie und Neostratotypen. Pl. , Dacien, Bd. IX, Ed. Academiei Române, Bucureşti, p. 506-518.

Rădulescu, C., Samson, P. \& Ştiucă, E. 1998, Relationships and correlation of the Pliocene faunas of the Dacic Basin, Romania. Romanian Journal of Stratigraphy, 78: 155-163.

Rădulescu, C., Samson, P., Petculescu, A. \& Ştiucă, E. 2003, Pliocene Large Mammals of Romania. In En torno a Fósiles de Mamiferos: Datación, Evolución y Paleoambiente (López-Martinez, N., Peláez-Campomanes, P. \& Hernández Fernández, M., Eds.), Coloquios de Paleontologia, Volumen Extraordinario, 1: 549-558.

Schlesinger, G. 1922, Die Mastodonten der Budapester Sammlungen. (Untersuchungen über Morphologie, Phylogenie, Ethologie und Stratigraphie europäischer Mastodonten). Geologica Hungarica, Series Geologica, 2 (1): 1-284.

Snel, E., Mărunțeanu, M., Macaleț, R., Meulenkamp, J.E. \& van Vugt, N. 2006, Late Miocene to Early Pliocene chronostratigraphic framework for the Dacic Basin, Romania. Paleogeography, Paleoclimatology, Paleoecology, 238: 107-124.

Simionescu, I. 1930, Vertebratele Pliocene de la Măluşteni (Covurlui). Academia Română, Publicațiile Fondului „Vasile Adamachi”, 9 (49): 1-69.

Simionescu, I., Barbu, V. 1943, Paleontologia României, Ed. „Cartea Românească”, Bucureşti, 120 p.

Tassy, P. 1977, Découverte de Zygolophodon turicensis (Schinz) (Proboscidea, Mammalia) au lieu-dit Malartic a Simorre, Gers (Vindobonien moyen); implications paléoécologiques et biostratigraphiques. Géobios, 10 (5): 655-669.

Terzea, E. 1983, Evoluția faunei terestre. In Geografia României, 1. Geografia fizică, Ed. Academiei R.S.R., Bucureşti, p. 444-450.

Terzea, E. 2005, Ansambluri de mamifere pliocene din Bazinul Dacic (România) şi semnificaţia lor ecologică şi paleoclimatică. Studii şi Comunicări, Ştiințele Naturii, Muzeul Olteniei Craiova, XXI: 9-13.

Tobien, H. 1996, Evolution of Zygodons with Emphasis on dentition. In The Proboscidea. Evolution and Palaeoecology of Elephants and Their Relatives (Shoshani, J. \& Tassy, P., Eds.): 76-85.

Tsoukala, E. 2000, Remains of a Pliocene Mammut borsoni (Hays, 1834) (Proboscidea, Mammalia) from Milia (Grevena, W Macedonia, Greece). Annales de Paléontologie, 86 (3): 165-191. 
PLATE I
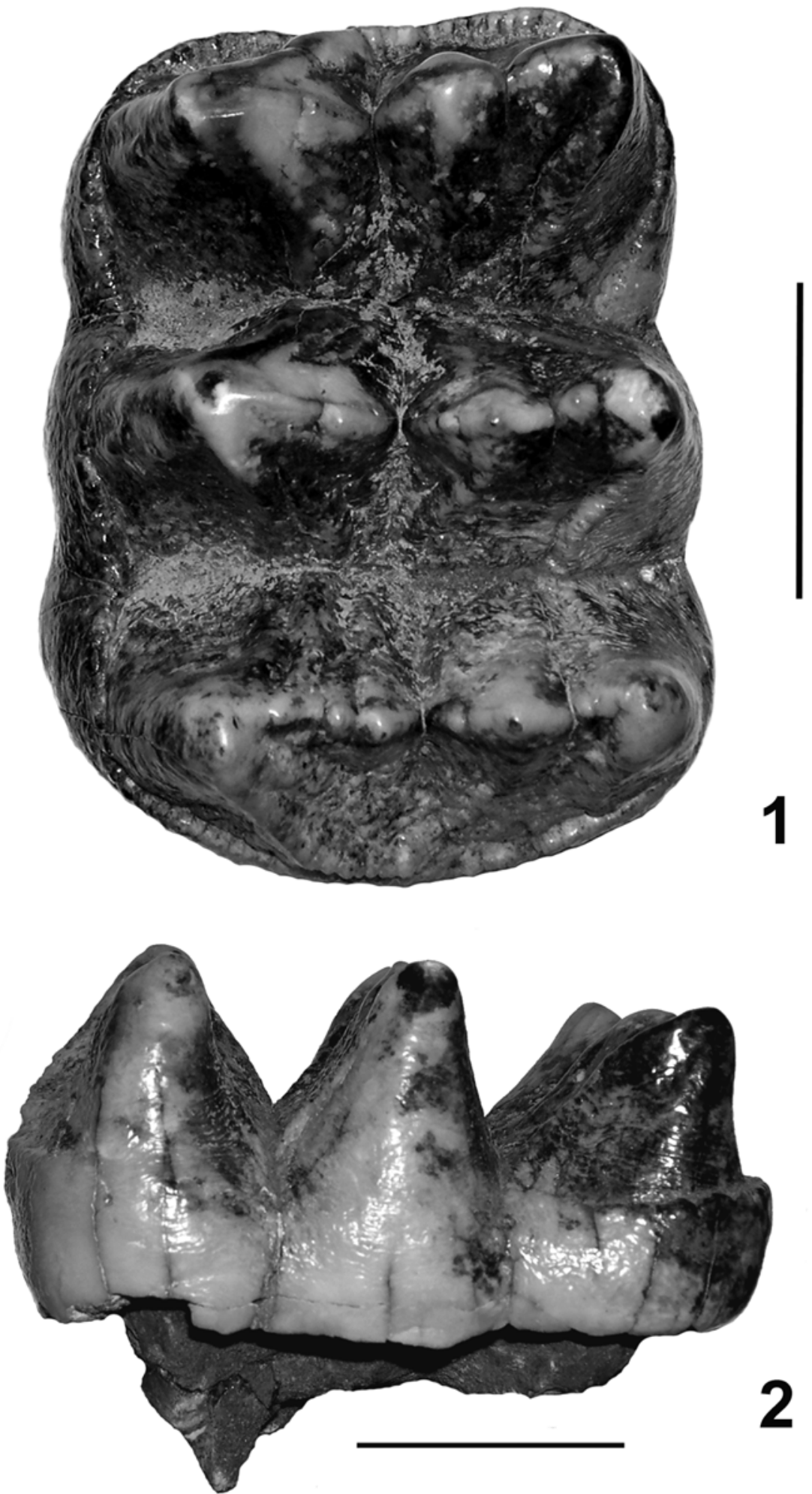

Plate I. M. borsoni, left M2, Lower Pliocene (Dacian), Husnicioara (scale bar-40 mm)

Fig. 1. Crown view;

Fig. 2. Outer view; 